ROCZNIKI KULTUROZNAWCZE

Tom XI, numer $1 \quad-\quad 2020$

DOI: http://dx.doi.org/10.18290/rkult.2020.11.1-3

MARCIN REBES

\title{
INTEGRACJA I RELACJE MIĘDZYKULTUROWE WCZORAJ I DZISIAJ — FILOZOFIA MIGRACJI
}

\section{WPROWADZENIE}

Integracja europejska i relacje międzykulturowe w państwach narodowych to dwa ważne problemy, z którymi boryka się współczesna Europa. Dochodzi do nich jeszcze zjawisko emigracji i migracji ludności. W takiej sytuacji współcześni Europejczycy muszą poszukać wspólnej płaszczyzny integrowania się ludności i społeczeństw bardzo zróżnicowanych pod względem kulturowym.

W okresie rewolucji francuskiej doszło do pewnego przełomu: państwa skupione wokół monarchy stały się państwami narodowymi, w których ważną rolę odgrywały wspólne dążenia, wspólne cele. Państwa narodowe powstają na gruncie różnych grup etnicznych, tradycji, religii i kultur lokalnych, z którymi obywatele identyfikują się, tworzą pewną jedność połączoną wspólną historią i wytyczonymi celami. Łączy ich wspólna, chociaż zróżnicowana, kultura i język. Także religia, światopogląd czy przyjmowane zasady moralne wpływają na tworzenie się pewnych obrazów, metafor, symboli, które są ważne dla procesu identyfikowania się z narodem. Państwa, które skupiały się wokół korony, monarchy, stają się państwami, w których kluczową rolę odgrywa naród. Powstaje jednak idea państwa jednorodnego. To zróżnicowanie wokół jednego narodu jest inspirujące, ale niesie z sobą różnego rodzaju niebezpieczeństwa, na przykład porzucenie pierwotnych więzi kulturowych. W tych państwach powstaje konkurencja dominujących tradycji, które wchodzą z sobą w różnego rodzaju konflikt. Odsuwa się też

Dr hab. Marcin Rebes - Uniwersytet Jagielloński, Wydział Studiów Międzynarodowych i Politycznych, Instytut Europeistyki, Zakład Filozofii Europejskiej; adres do korespondencji e-mail: marcin.rebes@gmail.com. ORCID: https://orcid.org/0000-0002-1318-1459. 
perspektywa budowania wspólnej europejskiej świadomości. Na przeszkodzie atomizacji $\mathrm{w}$ ramach powstających państw narodowych stoi wspólna przeszłość kultury europejskiej, ale również nauka i sztuka, które wykraczają poza perspektywę narodową. Wiążą one z sobą różnego rodzaju społeczności, różne kultury.

Proces tworzenia państw narodowych powoduje, z jednej strony, upowszechnianie idei ogólnoludzkich i pobudza do aktywności społecznej i politycznej środowiska, grupy społeczne, dotychczas biernych poddanych władzy monarszej, z drugiej zaś strony prowadzi do rozczłonkowywania i do skupiania się na celach narodowych kosztem wspólnych wartości. Również współczesna nauka sprawiła, że pewne szlachetne idee uniwersalne skupione wokół człowieka ustąpiły miejsca rozwojowi technicznemu, cywilizacyjnemu. Ten rozwój na pewno był potrzebny, ale przyniósł też zagrożenia, o których wspominali filozofowie, poeci, ludzie nauki. Jednym $\mathrm{z}$ nich jest skupienie się w swojej własnej świadomości na sobie. Ta tendencja wyparła myślenie uniwersalistyczne, silnie obecne w pierwszych wiekach chrześcijaństwa. Upadek kultury mieszczańskiej, wieszczony przez Nietzschego, dokonuje się jednak na początku XX wieku, gdy wybuchają kolejne wojny światowe. Ich podstawą jest chęć narzucenia własnych narodowych wpływów innym państwom. Nie będziemy jednak omawiać problemu pod kątem historycznym, lecz kulturowym - doprowadzenia do wyparcia „innego”, bo pod tą innością ukazuje się wcześniejsze zróżnicowanie etniczne, kulturowe, religijne. Po wojnie Europa stanęła przed poważnym wyzwaniem, jakim jest szukanie wspólnej płaszczyzny, na której można by rozwiązywać różne spory i konflikty międzynarodowe. W przeddzień konfliktów zbrojnych zaczęły powstawać organizacje zrzeszające kolejne państwa w celu ochrony praw człowieka. Po wojnach kluczową rolę odegrał Robert Schuman, który, zatroskany o losy Europy, szukał wspólnych wartości, by zamienić wrogość między społecznościami, państwami, kulturami na współpracę. Odpowiedzią na jego poszukiwanie jest zasada solidarności, która wiąże z sobą kulturowo, powraca do korzeni skoncentrowanych na człowieku. W tym sensie ponownie pojawia się problem integracji i roli ,innego" w naszym poszukiwaniu siebie, naszych wspólnych uniwersalnych wartości. Jak powie Fukuyama, podstawą dla przestrzeni społecznej, ekonomicznej jest kultura. To ona ma wpływ na nasze działanie społeczne $\mathrm{i}$ handel, także na nasz stosunek do szeroko rozumianego doświadczenia „innego"1.

\footnotetext{
${ }^{1}$ Pojmowanie ,innego” jest, z jednej strony, wynikiem wykształcenia pewnej formy otwartości, wypływa z kultury, z której wyrastamy, z drugiej zaś doświadczenie „innego” oddziałuje na
} 
W niniejszym artykule chciałbym omówić rolę integracji europejskiej oraz relacji międzyludzkich i międzykulturowych we współczesnym świecie. Moim celem jest ukazanie wzajemnej zależności między procesem integracji europejskiej i budowaniem modelu, w którym mogłyby współistnieć obok siebie różne kultury. Chcę skupić się na opisie wybranych zjawisk i na pokazaniu sposobu ich rozumienia. Posłużę się w tym celu refleksją fenomenologiczno-hermeneutyczną.

Artykuł składa się z dwóch części.

W pierwszej części koncentruję się na problemie integracji, odwołując się do historii kultury europejskiej. Pytanie o powody dążenia do integracji europejskiej implikuje kolejne - o tożsamość. To w jej obliczu ukazuje się relacja $j a$ do siebie, ale również $j a$ do innych. Właśnie przez pryzmat tych relacji wyłania się problem kultury i jej odniesienia do innych kultur. Od zarania dziejów człowiek, konfrontując się z różnymi kulturami, przejmował wiele elementów do własnej, ale także wpływał na inne.

W drugiej części zajmuję się problemem relacji między różnymi kulturami przez pryzmat procesów migracyjnych $\mathrm{w}$ Europie oraz wynikających stąd zakłóceń $\mathrm{w}$ integracji. Zagrożenia pochodzące $\mathrm{z}$ zewnątrz, takie jak wzrost terroryzmu, ale również spowodowane zjawiskami ksenofobii i skrajnego nacjonalizmu (izolacjonizm) mogą zagrozić bezpieczeństwu Europy. Jedynym sposobem zapobiegania tym zagrożeniom jest integracja, która powinna być odzwierciedleniem człowieka i zrozumienia przez niego własnej wspólnoty.

Zacznijmy zatem od przedstawienia etymologii pojęcia integracji oraz ukażmy przykłady integracji europejskiej w historii. Zabieg ten pomoże nam lepiej zrozumieć, czym jest integracja i jakie są jej podstawy w kulturze europejskiej.

\subsection{Etymologia pojęcia integracja}

Pojęcie „integracja” wywodzi się z języka łacińskiego. Rzeczownik integratio znaczy 'odnowienie, przywracanie, restart', a czasownik integrare 'wznawiać, powtarzać, przepisywać', ale także 'odświeżać, wzmacniać, uspokajać' ${ }^{2}$. W tym sensie integracja to powrót do wcześniejszego stanu. Istnieje też słowo integritas, które oznacza 'normalność, uczciwość, spra-

kształtowanie się kultury. Fukuyama zauważa, że na procesy ekonomiczne, polityczne ma wpływ kultura. Twierdzi tak m.in. w książce Zaufanie: kapitat spoleczny a droga do dobrobytu, przeł. Anna i Leszek Śliwa (Warszawa, Wrocław: Wydawnictwo Naukowe PWN, 1997).

${ }^{2}$ Stownik łacińsko-polski, red. Józef Korpanty, t. 2 (Warszawa: Wydawnictwo Naukowe PWN, 2003), 103. 
wiedliwość i niewinność'. Integracja zatem przywraca i odnawia coś, co ma swój początek wcześniej. Dlatego przeszłość stanowi inspirację dla współczesnego odkrywania sensu pojęcia integracja i jego znaczenia dla naszej kultury. Powrót do przeszłości nie oznacza, że odrzucamy teraźniejszość, lecz że uzupełniamy coś, co ma swój początek w przeszłości, i wracamy do źródła kultury europejskiej. Integracja europejska wiąże z sobą wiele wspólnych tradycji i wspólnych wartości, które pojawiają się od początku kształtowania się kultury w Europie. Integracja wyraża dążenie do połączenia się w jedno, jest również rozumiana jako uzupełnienie przy zachowaniu inności lub różnic. Ten proces integracji nie jest niczym nowym, ale oznacza powrót do wspólnego źródła. Dlatego powinniśmy odwołać się do korzeni kultury europejskiej i zapytać o to, jakie są wspólne wartości i jaki mają wpływ na naszą kulturę.

\subsection{Proces integracji i dezintegracji W przeszŁości}

Jak pokazuje historia, proces integracji ma długą tradycję. Dziś idea integracji opiera się na wspólnych tradycjach i wspólnych uniwersalnych wartościach ${ }^{3}$. Najważniejszą wartością jest sam człowiek. Od początku powstania kultury europejskiej istotnym problemem staje się wolnośc ${ }^{4}$, w nowożytności jest to wolność jednostki. Inne ważne wartości to prawda, dobro, a także piękno. Ich rozumienie wpływa na tworzącą się kulturę, także na stosunek do innych kultur. W horyzoncie tych wartości Europa integruje się.

U podstaw kultury europejskiej leży kultura materialna Azji (kultura sumeryjska, akadyjska, babilońska i fenicka). Fenicjanie, wiążąc te kultury z sobą, dokonali synkretyzmu i stali się prekursorami kultury europejskiej, ale także procesu jej integracji.

Integracja w kontekście wiary w wolność ujawnia się w mitach o Europie, pięknej córce Agenora, fenickiego króla Tyru, która została porwana przez Zeusa. Zakochany w Europie Zeus uciekł się do podstępu: przybrał postać pięknego śnieżnobiałego byka ze złotymi rogami i pojawił się na łące, na której Europa bawiła się wraz z towarzyszkami. Europa, zwiedziona delikatnością byka, siadła mu na grzbiecie, a ten, korzystając z okazji, porwał ją na

\footnotetext{
${ }^{3}$ Mimo że różne kultury narodowe, kształtujące kulturę europejską, znacznie różnią się i mają różne doświadczenia, to łączy je wspólna historia, ale także wartości, do których dążymy, czyli dobro, prawda, wolność, a współcześnie także odpowiedzialność oraz solidarność.

${ }^{4}$ Początkowo wolność była rozumiana przez pryzmat przynależności do cesarstwa, by z czasem przekształcić się w wolność jako niezależność od świata materialnego, czyli ukazywać się $\mathrm{w}$ sferze psyche.
} 
Kretę. Tam Europa urodziła swoich synów. Później, porzucona przez Zeusa, została żoną króla Krety. Byk, który ją porwał, został umieszczony na niebie. Mit osiedlenia się Europy na Krecie wiąże się również z opuszczeniem domu rodzinnego, migracją. Król Agenor kazał swoim trzem synom szukać siostry i nie wracać do domu bez niej. Fojniks udał się do Afryki, Kiliks przemierzał Azję Mniejszą, Kadmos dotarł do Delf, ale żaden nie znalazł Europy. Wszyscy trzej po bezowocnych poszukiwaniach musieli znaleźć miejsce dla siebie poza ojczyzną - Kadmos na przykład zamieszkał w Tebach, założonym przez siebie mieście.

Mit o Europie ukazuje nie tylko opuszczenie domu, ale także powstanie nowej kultury, nowej tożsamości, która wyrasta z niewoli, porwania, by stać się zalążkiem nowej kultury, dla której wolność będzie stanowiła wartość. W mitach wolność pojawia się sporadycznie albo wcale. Jej miejsce zajmuje przeznaczenie, Ananke, lecz z czasem ta wartość staje się istotna dla kultury wyrosłej z mitu o porwanej przez Zeusa Europie.

Z kultury Achajów, Dorów i Jonów wyrasta cywilizacja Morza Egejskiego, która inicjuje tworzenie kultury europejskiej. Kultura achajska, dorycka i jońska różnią się od siebie, ale w konfrontacji z barbarzyńcami cechuje je

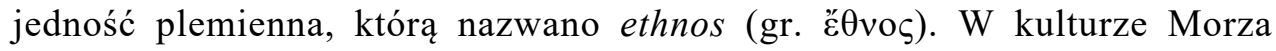
Egejskiego powstały pierwsze organizacje społeczne, a także pierwsze organizacje polityczne, które wyrosły z lokalnej społeczności. Społeczność była początkowo interpretowana jako oikos (gr. oĩ mieszka, czyli dom, potem rodzina zmienia się w instytucje polityczne ${ }^{5}$.

Pojawia się również mit i filozofia. Początkowo filozofowie, szczególnie jońscy: Anaksymander, Anaksymenes i Heraklit, stawiają pytanie o arche (gr.

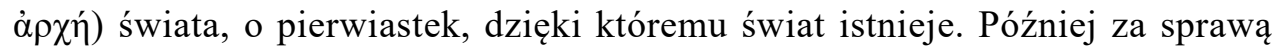
Pitagorasa i jego uczniów, którzy zajmowali się nie tylko arche, filozofia za-

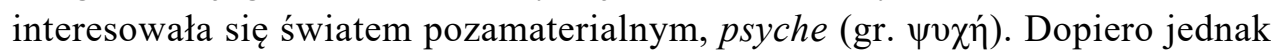
żyjący na przełomie V i IV wieku p.n.e. Platon i Arystoteles położyli podwaliny pod współczesną europejską filozofię, w której kluczową rolę odgrywa dobro. Systematyzują znaczenie i rozumienie poglądów na temat natury świata, ale także zwracają uwagę na psyche i duchy, inicjując badania nad człowiekiem, a także jego wolnością, brakiem determinacji ze strony natury ${ }^{6}$.

W Imperium Rzymskim myśl grecką uzupełniał porządek prawny. Rozszerzał kategorie kultury o kategorie duchowe, ale i cywilizacyjne. Świat

\footnotetext{
${ }^{5}$ Stownik grecko-polski, red. Zofia Abramowiczówna, t. 3 (Warszawa: PWN 1962), 250.

${ }^{6}$ Werner JAEGER, Teologia wczesnych filozofów greckich, przeł. Jerzy Wocial (Kraków: Homini, 2007), 149-150.
} 
„wartości” dotyczył wówczas nie tylko obywateli Rzymu, ale także wszystkich krajów i społeczności. Te wspólne wartości i kultura duchowa doprowadziły do jedności europejskiej kultury i cywilizacji. Doszło nie tylko do integracji nowych terenów z Imperium, ale także do położenia nacisku na kulturę prawną, dążącą do odkrycia prawdy, którą pojmuje się przez pryzmat zgodności tego, jak jest, z sądem o tych rzeczach.

Ogromny wpływ na rozwój kultury europejskiej wywrze chrześcijaństwo. Stoickiej tolerancji wobec świata przeciwstawiało ono miłość bliźniego, czyli do drugiego człowieka. To doświadczenie miłości bliźniego i miłowania nawet nieprzyjaciół odciśnie ogromne piętno na kulturze i jej stosunku do innych kultur. We wczesnych wspólnotach chrześcijańskich rozwijała się wiara w Chrystusa, której wyznawcy pozostawali pod wpływem kultury greckiej. Chrześcijaństwo sięga po filozofię stoicką, pitagorejczyków, ale również Platona czy Arystotelesa, szczególnie poprzez św. Pawła, obywatela Rzymu, który stał się jednym z chrześcijan? ${ }^{7}$ Ś Ś. Paweł odwołuje się pośrednio do myśli greckiej i rzymskiej, w tym do pojęcia duszy czy właśnie wolności, „ku której wyzwala nas Chrystus” (por. Ga 5,1) ${ }^{8}$. Chrześcijaństwo sprawiło, że idea wolności, pojawiająca się u Sokratesa, Platona czy Arystotelesa, stała się wolnością człowieka jako jednostki. Wolność dotyczyła jednostek i koncentrowała się na człowieku i jego relacji z Bogiem. Człowiek został stworzony na obraz i podobieństwo Boga. Chrześcijaństwo wprowadziło pojęcie nieśmiertelności duszy i dobra, które ma charakter uniwersalny. Idea braterstwa poczęła budować nową jedność.

\footnotetext{
${ }^{7}$ Św. Paweł pobierał nauki w szkole rabinistycznej Gamaliela (Dz 22,3), w której obok prawa poznawano także filozofię, m.in stoicką (np. Seneki), a także pitagorejczyków czy w końcu poglądy Platona i Arystotelesa. Św. Paweł nawiązuje do tych poglądów szczególnie w swoich listach, aby wytłumaczyć, czym jest wiara w Chrystusa. Często używa filozofii, aby wykazać, czym w odróżnieniu od niej jest bycie chrześcijaninem. W ten sposób mógł dojść z przesłaniem Chrystusa do ludzi, którzy znali filozofię. Pewne myśli, jak teoria formy czy życia wiecznego, są podobne do filozofii Platońskiej, lecz trzeba także brać pod uwagę fakt, że sam Platon pobierał nauki w szkole horyckiego kapłana w Memfis. Tam poznał m.in. teorię, ideę duszy nieśmiertelnej czy zmartwychwstania ciała. Por. Guarino Guarini, Żywot Platona, przeł. Tomasz Płóciennik, w: Humanistyczne żywoty filozofów starożytnych, red. Włodzimierz Olszaniec i Krzysztof Rzepkowski, seria: Biblioteka Renesansowa 1 (Warszawa: Wydawnictwa Uniwersytetu Warszawskiego, 2008), 225.

${ }^{8}$ Św. Paweł pojmuje wolność przez pryzmat miłości Chrystusa do człowieka i powołania chrześcijan do kierowania się wiarą i służenia innym. Stwierdza: „Wy bowiem, bracia, do wolności zostaliście powołani, ale nie do tej wolności, która służy naturalnym skłonnością ludzkim, lecz która — ożywiona miłością — każe wzajemnie sobie usługiwać” (Ga 5,13). W starożytności posługiwano się pojęciem przeznaczenia, chrześcijaństwo przekształca je w łaskę, której podstawą jest wolność Boga i człowieka.
} 
Kolejnym etapem $\mathrm{w}$ procesie integracji kultury europejskiej był kryzys, który doprowadził do upadku zachodniego cesarstwa rzymskiego i przeniesienia stolicy „superpaństwa” do Konstantynopola, tj. do cesarstwa wschodniorzymskiego. Rozpoczął się stopniowy proces dezintegracji kultury i cywilizacji europejskiej.

Nowe nadzieje na urzeczywistnienie idei Christianitas przyniosło powstanie państwa frankońskiego (Regnum Francorum) ${ }^{9}$. Do jedności kultury europejskiej przyczyniła się także stosowana przez możnowładców polityka wchodzenia w różnego rodzaju koligacje rodzinne. Oprócz wydarzeń politycznych bardzo ważną rolę odgrywał w tym czasie fakt powstawania uniwersytetów, które łączyły nie tylko profesorów i żaków z jednego państwa, ale wykraczały poza granice, tworząc naukę europejską. Podobne zasługi miała sztuka, ale też szlaki handlowe. Szczególnym elementem wiążącym jest wówczas kultura oparta na pewnych zasadach, które można pokrótce określić jako wspólny system myślenia, metafizyka, jak i humanizm. Zachowanie wspólnych wartości było możliwe dzięki chrześcijaństwu i kulturze europejskiej, sięgającej korzeniami do starożytnej Grecji, jak też posługiwanie się wspólnym językiem - najpierw greckim, potem łacińskim. Przez kulturę i w kulturze powstają symbole, alegorie, pojęcia abstrakcyjne wykorzystywane w wielu kulturach lokalnych księstw i mocarstw.

Reformacja w krajach niemieckojęzycznych przyniosła pewne zmiany, takie jak porzucenie łaciny i skoncentrowanie się na językach narodowych, a także tworzenie się nowej klasy, która coraz bardziej świadomie będzie chciała uczestniczyć w sprawowaniu władzy. Mimo podziału Kościoła została zachowana wspólna metafizyka i - co najważniejsze - zainteresowanie człowiekiem i jego zdolnościami do poznania siebie i świata. Po reformacji we Francji Kartezjusz postawił pytanie o poznanie człowieka, wprowadzając pewną nową metodologię, której celem jest znalezienie tej sfery, która jest bardziej pewna niż świat zewnętrzny. Koncentrując się na procesie myślenia, które odpowiada tym wymogom metodologicznym, stał się inspiratorem myśli nowożytnej i racjonalizmu europejskiego. W przeciwieństwie do niego filozofowie brytyjscy, tacy jak David Hume i George Berkeley, odwoływali się do świata poznawanego przez zmysły. Świat człowieka zaczyna się dzielić na oparty na zasadach racjonalnych oraz na zmysłowych. Rozwój nauki i filozofii przyczynił się do nowej zmiany kulturowej, która wraz ze zniesieniem systemu feudalnego i społeczeństwa stano-

\footnotetext{
${ }^{9}$ M. David Knowles i Dmitri Oвolensky, Historia Kościoła, t. 2, przeł. Ryszard Turzyński (Warszawa: Instytut Wydawniczy PAX, 1988), 33 i 55.
} 
wego spowodowały, że populacja zaczyna przenosić się do miast, tworząc nową grupę społeczną. Świat wartości staje się coraz bardziej szczegółowy. Nie bez znaczenia będzie wymiana kulturowa w czasie kolonializmu, która jest naznaczana piętnem brutalizmu, ale również wymianą tak produktów, jak i myśli, które pozwolą spojrzeć na świat przez pryzmat innych kontynentów. Wymiana produktów ma, z jednej strony, wpływ negatywny ze względu na niewolnictwo, z drugiej zaś pozytywny, ponieważ na nowych obszarach powstają plantacje nowych roślin, które ludność lokalna, ale także i Europejczycy, będzie wykorzystywać, broniąc się przed głodem. Z czasem preferencje kulinarne sprawią, że kultura smaku rozwinie się na wszystkich kontynentach, także w państwach narodowych, tworząc specyficzną kuchnię.

Powszechne wartości, które zachowywał Kościół, w czasie rewolucji francuskiej (1789 r.) przekształciły się w wartości, których główną cechą jest to, że służą do czegoś, mają charakter utylitarny ${ }^{10}$. I w tym jednak czasie pojawiają się takie wartości, jak wolność, równość i braterstwo, które cechowały także wcześniej filozofów czy chrześcijaństwo. Rewolucja francuska przyczyniła się do powstania państw narodowych, które zastąpiły monarchię. W okresie napoleońskim tendencja do budowy superpaństwa została odnowiona, ale na gruncie nowej rzeczywistości, ,nowego” systemu wartości.

\subsection{Powstanie państw NARODOWYCH I UNIWERSALNE WARTOŚCI}

Państwa narodowe początkowo bazowały na różnicach etnicznych, kulturowych i religijnych. Spajał je wspólny cel, jakim jest powstanie narodu. W początkowej fazie naród mogły tworzyć różne grupy, które chciały budować wspólnotę. $Z$ czasem zaczęły charakteryzować się spójnością, jednością. W państwach narodowych obywatele mogli identyfikować się ze społecznością, dokładając jakiś własny element do jej jedności. Pojawiało się braterstwo, które oznaczało również oddzielenie się od innych wspólnot, narodów. Ciekawym przykładem występowania tego zjawiska jest coraz większe zróżnicowanie kuchni w poszczególnych regionach, aż do utworzenia kuchni „,narodowych". W tym czasie we Francji powstała bowiem nowa kultura stołu ${ }^{11}$.

\footnotetext{
${ }^{10}$ Jacob Leib TALmon, „O demokracji totalitarnej”, Znak 1992, nr 4 (443): 69. Są to fragmenty książki Talmona zatytułowanej The Origins of Totalitarian Democracy (London: Secker and Wartburg, 1952).

${ }^{11}$ We Francji do rozpowszechnienia się kuchni regionalnych przyczyniła się wydarzenia towarzyszące wybuchowi rewolucji francuskiej. W tym czasie kuchnia wyższa, która była domeną arystokracji, staje się częścią życia społecznego obywatela. Powstały książki kucharskie, które popularyzowały kuchnię francuską. Do powstania kuchni regionalnej przyczynił się także wolny rynek.
} 
Państwa narodowe, chroniąc obywateli przed rozmyciem własnych idei wspólnoty, przyczyniły się do powstawania granic i do wyodrębnienia własnej kultury. Wciąż jednak pozostały pewne przestrzenie, które mają charakter uniwersalny, takie jak nauka czy sztuka. Wzrastała też świadomość jednostki, w tym także świadomość praw i obowiązków obywateli wobec siebie i państwa. Wewnątrz państw doszło do wewnętrznego napięcia i zmian społecznych. Wyłoniły się nowe elity, które miały być odpowiedzialne za stabilizację wewnątrz państwa. Pojawiły się również wojny, jak chociażby te prowadzone przez Napoleona, które przyczyniały się także do ruchów ludności.

Ustanowienie państw narodowych jest wynikiem, z jednej strony, rosnącej świadomości człowieka i chęci bycia odpowiedzialnym za własne państwo, z drugiej zaś tendencji do oddzielania się od wspólnych korzeni. To, co wcześniej było przyczyną atomizacji lub zwiększenia ludzkiej świadomości, jest dziś podstawą powrotu do wspólnych korzeni, do wspólnej tradycji. Człowiek zrozumiał, że jest związany nie tylko z duchem narodowym, ale także wartościami uniwersalnymi. Ten zwrot ku wspólnym wartościom stymuluje nauka, filozofia lub religia. Rozwój nauk przyrodniczych, które opierały się początkowo na redukcji natury do rzeczywistości otaczającej, a także odrzucenie dotychczasowego porządku społecznego i moralnego, przyczyniły się w znacznym stopniu do migracji ludności do miasta i tworzenia nowych grup społecznych, w konsekwencji zaś wpłynęły na powstanie państw narodowych. Rozwój technologii opartej na naukach przyrodniczych i matematycznych daje możliwość skorzystania ze wspólnego dobra cywilizacji, popychając nas w kierunku odrodzenia się integracji. Nauki humanistyczne, dla których źródłem i inspiracją jest człowiek, stanowią tło i uzupełnienie.

Wilhelm Dilthey dostrzega potrzebę oddzielenia nauk przyrodniczych od nauk humanistycznych, proponując refleksję opartą na zrozumieniu ${ }^{12}$. Wskazuje na potrzebę skoncentrowania się na interpretacji, na wykładni sensu, która charakteryzuje nauki humanistyczne. W odróżnieniu od nich nauki przyrodnicze skupiają się na powtarzalności zdarzeń, mogących służyć powstaniu zasad kierujących światem. Analiza hermeneutyczna, podobnie jak fenomenologia, potrzebuje refleksji nad subiectum, które wyraża ja. Filozofia od początku swojego istnienia pyta o źródło, o podstawę istniejącego świata. Stawiali to pytanie filozofowie jońscy, ale również filozofowie żyją-

Por. Rachela LAUDEN, Cusine and Empire: Cooking in World History (Berkeley, Los Angeles, London: University of California Press, 2014), 224.

${ }^{12}$ Wilhelm DiLthey, Einleitung in die Geisteswissenschaften. Versuch einer Grundlegung für das Studium der Gesellschaft und der Geschichte, t. 1 (Lepizig: Verlag Duncker und Humboldt, 1883), 172. 
cy w XX-wieku. Ci pierwsi odpowiedzi na pytanie o źródło szukali w świecie, później zaś to pytanie przekształciło się w inne: kim jest człowiek? Jest istotą społeczną, polityczną czy działającą?

W 1923 r. Martin Buber doszukiwał się źródłowego doświadczenia w parze „Ja-Ty”. Dobro w związku z tym pojawia się w nowym świetle. Dobro konstytuuje się między nami, między tobą i mną. W tej filozofii, zwanej filozofią dialogu, rozmówca odgrywa ważną rolę. To wraz z nim odkrywam prawdę o sobie. Filozofia dialogu dostrzega w kulturze europejskiej wynaturzenie, widoczne od czasów Kartezjusza, które polega na egocentryzmie, na koncentrowaniu się na podmiocie, co może mieć poważne konsekwencje.

Obok kultu ego pojawia się także redukcja myślenia do tego, co praktyczne, co jest wynikiem dominacji nauk przyrodniczych, oraz postęp techniki, sprowadzający świat do rzeczywistości otaczającej. Kryzys nauk humanistycznych i upadek wartości, co wieszczył Friedrich Nietzsche, doprowadziły do „przewartościowania wartości”, do przesunięcia badań nad człowiekiem ze sfery kultury do sfery natury. Ta redukcja oraz koncentracja na dziejowości, w której państwa odkrywają cel swojego istnienia, doprowadzają do chęci podbojów, dominacji nad innymi państwami, a w konsekwencji do wybuchu dwóch wojen światowych. Pozostawione po wojnie zgliszcza kultury europejskiej wymagały odbudowy. Było to możliwe na gruncie powrotu do wspólnych wartości, do metafizyki, etyki, do nauki, która w sposób całościowy, holistyczny uchwyci istotę człowieka, jego człowieczeństwa, a także wyznaczy wspólny kierunek rozwiązywania konfliktów narodowych na drodze pokojowej. Pomysł ten zainspirował założycieli Unii Europejskiej Roberta Schumana $^{13}$ czy Alcide'a De Casperiego ${ }^{14}$. Schuman szukał wspólnych wartości, które zwiążą zwaśnione strony ${ }^{15}$. Wartością wspólną, której poszukiwał Schuman, stanie się później zasada solidarności. W niej kluczową rolę odgrywa jedność w różnorodności, jej zaś podstawą jest wspólna kultura.

Dzisiejszy kryzys integracji opiera się, z jednej strony, na napięciu między ideałem a rzeczywistym poczuciem integracji (nie zawsze obywatele Europy widzą empiryczny charakter integracji), z drugiej strony zaś na napięciu między partykularyzmem a wartościami uniwersalnymi (wartości jed-

\footnotetext{
${ }^{13}$ Robert Schuman, Dla Europy, przeł. Magdalena Krzeptowska (Kraków: Wydawnictwo Znak, 2009), 17, 18, 22, 26-28.

${ }^{14}$ Giuseppe Audisio i Albert ChIARA, Twórcy zjednoczonej Europy Robert Schuman, Konrad Adenauer, Alcide de Gasperi, przeł. Paweł Borkowski (Warszawa: Instytut Wydawniczy PAX, 2007), 69 .

${ }^{15}$ Schuman stwierdza, że Europa, zanim stanie się jednością w sensie obronnym i ekonomicznym, musi się stać wspólnotą kulturową. Schuman, Dla Europy, 22, 26, 34, 86.
} 
nostki i jej woli, tożsamość narodowa ponad wartościami uniwersalnymi). W obu przypadkach istotnym elementem niezrozumienia, czym jest integracja europejska, staje się niedostrzeganie konieczności powrotu do wspólnych korzeni, z których wyrosła tożsamość państw narodowych.

Europa po wojnie, po transformacjach ustrojowych odrodziła się w nowy sposób. Państwa narodowe w wyniku zmiany granic, ale również osiedlania się nowej ludności pozostawały państwami narodowymi, ale jednocześnie wielokulturowymi. Część migrantów przesiedlała się na skutek pauperyzacji do krajów europejskich, szczególnie do dawnych państw kolonialnych, ale także do tych, które bogaciły się i stawały się rajem dla ludności uboższej. Do wzrostu migracji przyczyniły się znacznie także inne czynniki, takie jak powszechność dostępu do mediów czy wzmożony handel. Najważniejszym jednak czynnikiem stała się ochrona praw człowieka, poszanowanie jego godności. To one mogły dawać migrantom i uchodźcom nadzieję na możliwość odnalezienia się w nowej przestrzeni.

\section{PROCESY MIGRACYJNE \\ ORAZ POWSTANIE PAŃSTW WIELOKULTUROWYCH W PAŃSTWACH NARODOWYCH}

Ruchy ludności spowodowały, że problem migracji stał się tak ważnym elementem jak kiedyś, u zarania kultury europejskiej. Państwa narodowe stawały się państwami wielokulturowymi. Mimo jednak istnienia państw narodowych w nauce i kulturze utrzymywała się powszechna zgodność co do panujących wartości i wyobrażeń, a także wizji transcendentalnych, podobnie w handlu, w którym komponentem uniwersalności był i jest wolny rynek i systemowa otwartość na wymianę handlową. Także wzajemne relacje między państwami sprawiły, że potrzebne stało się wzmocnienie wartości uniwersalnych, które są identyczne dla wszystkich.

W epoce industrialnej, o której pisze Francis Fukuyama, pojawiają się silne trendy migracyjne, ludność opuszcza stopniowo wsie i osiedla się w miastach, tworząc nową klasę. Później społeczeństwo dzieli się ze względu na funkcje i relacje społeczne. W tym czasie powstają poważne różnice społeczne, wynikające ze specjalizowania się obywateli w produkcji poszczególnych dóbr, które są używane przez społeczeństwa. Pierwotna nierówność, wynikająca z pochodzenia i stopnia zamożności, ustępuje miejsca egalitarności: każdy obywatel może dojść, przynajmniej potencjalnie, do zamożności. Pozycję należącą początkowo do szlachty i arystokracji zajmują inte- 
ligencja i właściciele przedsiębiorstw. Zaczynają oni spełniać funkcję stabilizatora sytuacji społecznej, politycznej i kulturowej. Na rynku dominują przedsiębiorstwa, które wytwarzają różne produkty, ale również rozwija się handel, obejmujący coraz szersze kręgi i tworzący strukturę globalną.

Obok handlu ważną rolę zaczynają odgrywać komunikacja, media i reklama. Dzięki reklamie powstają sieci handlowe, które prowadzą sprzedaż nie tylko lokalnie, ale także globalnie. Rozwój medialny przyczynia się do wzrostu znaczenia informatyki. Mówi się nawet o epoce informatycznej. Media społecznościowe oraz wyspecjalizowane programy komputerowe przeznaczone do poszczególnych typów zajęć sprawiają, że coraz ważniejszą sferą staje się informacja. Fukuyama zauważa, że w okresie informatycznym ważną rolę odgrywają wolność i równość ${ }^{16}$. Dodałbym do nich poczucie solidarności. Ludność w krajach rozwiniętych zajmuje się komunikacją społeczną i handlem, zakłady produkcyjne przenoszone są poza ich państwa, a działalność państw rozwiniętych sprowadza się do zarządzania produkcją.

W epoce informatycznej wzmacnia się tendencja do równości między ludźmi i zaspakajania podstawowych ich potrzeb, które dają możliwość samorealizacji. Zmienia się też struktura społeczna. Ludność jest zatrudniana na nowych stanowiskach. Pracują jako informatycy czy specjaliści od public relations. Naukowcy zajmują się naukami opartymi na psychologii, socjologii czy naukach przyrodniczych. Epoka informacyjna i globalizacja sprawiają, że dystans między ludźmi się skraca. Problem lokalny staje się problemem globalnym.

Poszukiwanie tego, kim jest człowiek, rozpoczęte przez Kartezjusza, a także powstanie państw narodowych sprawiły, że uwidocznił się ogólny problem integracji państwa. Większa świadomość sprawia, że obawa o swoje życie, o życie rodziny, o zapewnienie rodzinie bazy egzystencjalnej, przeradza się w obawę o państwo. Jak powiedzieliśmy wcześniej, rewolucja francuska spowodowała, że ten proces przybrał na sile.

Proces globalizacji jest wynikiem sytuacji zaistniałej po wojnach światowych, która miała zapewnić stabilizację w Europie. Jej fundamentem jest jednak kultura europejska, która od początku powstania opierała się na synkretyzmie różnych kultur.

Fukuyama uważa, że kultura wpływa na losy polityczne ${ }^{17}$. Można także stwierdzić, że polityka wywiera presję na wzmożenie zabiegów, mających na

\footnotetext{
${ }^{16}$ Francis FuKUYAMA, Wielki Wstrząs. Natura ludzka a odbudowa porządku społecznego, przeł. Hanna Komorowska i Krzysztof Dorosz (Warszawa: Politeja, 2000), 13.

${ }^{17}$ Ibid., 15.
} 
celu integrację kultury, która u podstaw ma wielokulturowość. Fukuyama, jak heglista, dostrzega dziejowość, w której urzeczywistnia się prawda o człowieku. Dotyczy to także epoki industrialnej i informatycznej. W tych dwóch epokach doszło nie tylko do wzrostu znaczenia narodu, ale też do zwrócenia się ku wartościom uniwersalnym. Kluczowe stały się wartości, które powinny obowiązywać nas samych, ale także innych ludzi i inne narody. Chodzi tu przede wszystkim o prawa człowieka, które szczególnie w XX wieku stały się podstawą kultury. Oczekuje się, że nie tylko konkretny naród będzie szanował wartość człowieka i jego wolność, ale każdy kraj i każda nacja. Wszyscy obywatele i wszystkie narody chcą poszanowania wspólnych wartości. Integracja jest tylko odpowiedzią na powrót do wspólnych kulturowych korzeni i wartości. Przeszkodą w integracji jest kryzys wartości, co wynika z ich niezrozumienia. Zamiast postrzegać je przez pryzmat doświadczeń innych i mojej tożsamości, opieram je na abstrakcyjnych koncepcjach, które przyczyniają się nie tylko do kryzysu wartości, ale także do kryzysu integracji.

Strach związany z kryzysem wartości, nauki, kultury i społeczeństwa zwiększa się przez zjawisko wzmożonej migracji, która jest odbierana jako zagrożenie zewnętrzne. Proces migracji wpływa na nastroje społeczne z powodu kryzysu wartości.

Proces mieszania się kultur w wyniku procesów migracji ma długą historię i pojawił się, zanim powstały państwa narodowe czy monarchie. Wynikał on z sytuacji ludności, która chciała łatwiej zdobywać jedzenie czy schronienie dla rodziny.

\subsection{Migracja Ludności Wewnątrz Europy i spoza Europy}

Współczesny problem integracji europejskiej jest wynikiem migracji dużej części ludności nie tylko wewnątrz Unii, ale przede wszystkim spoza jej granic. Obecnie powód podjęcia decyzji o zmianie miejsca zamieszkania może być inny niż miedyś. Jednym $\mathrm{z}$ podstawowych jest zła sytuacja ekonomiczna (migracja ekonomiczna) lub polityczna (polityczna). Problem ten można rozpatrywać nie tylko w kontekście społecznym, politycznym, kulturowym, ale także filozoficznym. Filozofia pyta nie tylko o warunki, przyczyny i zależności, ale także o źródło naszej tożsamości i relacji z innym człowiekiem, również o kulturę i tradycje, które mają emigranci. Migracja obejmuje zjawisko alienacji, usuwania człowieka $\mathrm{z}$ tradycji i kultury jego przodków. W obliczu innej kultury migrant staje się obcy. Staje się także innym dla siebie. Dlatego szuka odpowiedzi na pytanie o swoją tożsamość. Kim jestem? Co jest mi bliskie? 
Nie tylko emigrant lub uchodźca musi zadać pytanie o siebie i zobaczyć nową sytuację, w której staje się innym dla innych. Ta analiza drugiego pokazuje dwa wymiary, które są bardzo ważne w sytuacji spotkania z innym. Po pierwsze, gdy emigrant przybywa do innego kraju, nawiązuje pierwszą relację $\mathrm{z}$ autochtonem i jest traktowany jako gość. Na ten temat pisze Emmanuel Lévinas, który obserwuje tę relację $\mathrm{z}$ perspektywy etyki ${ }^{18}$. Po drugie, kiedy gość osiedla się i potrzebuje silniejszych relacji z ludźmi, którzy żyją na danym terenie od pokoleń, staje się wówczas migrantem. Filozofia migracji staje się ważna, jeśli nie najważniejsza dla nas, kiedy koncentrujemy się na źródłowym doświadczeniu siebie i innego. W tej relacji nawiązujemy kontakt i spotykamy się twarzą w twarz. Oba rodzaje relacji różnią się od tego, czego się boję. W pierwszym przypadku obawiam się o siebie, w drugim - o moją kulturę i społeczeństwo. W obu przypadkach chodzi o innego, z którym chcę nawiązać więź.

To, co łączy te dwa przypadki, to mój związek z innym, który staje się częścią mojego świata. Jest to ściśle związane $\mathrm{z}$ doświadczeniami tożsamości, które każdy z nas posiada.

U podstaw kryzysu migracyjnego jest doświadczenie etyczne, które odsłania źródłowe doświadczenie siebie, swojej tożsamości. Stosunek do przybyszów jest częścią stosunku do siebie. Dopiero doświadczenie etyczne umożliwia wszelkie racjonalne wydawanie sądów. U podstaw relacji z innymi, z której wyłania się moja tożsamość, jest doznanie zmysłowe bliskości, solidaryzowania się z drugim.

\subsubsection{Problemy migraCjI PRZEZ Pryzmat Pytania o JA}

Postać innego odgrywa w kulturze europejskiej ważną rolę. To dzięki niemu ja odnajduje sens własnego istnienia. Ta filozofia ma u swojej podstawy miłość bliźniego. Kryzys wartości, który nasilił się szczególnie mocno po nietzscheańskiej krytyce tradycji judeochrześcijańskich, ponownie traci znaczenie w konfrontacji z symboliką innego. Odwieczne pytanie o tożsamość, na które jedyną odpowiedzią było zestawienie człowieka z charakterystyczną dla niego czynnością, ukazywało niemoc filozofii. Dopiero ja rozpatrywane przez pryzmat spotkania pozwoliło określić, kim jesteśmy. Poprzez skoncentrowanie się na relacji między człowiekiem a człowiekiem,

\footnotetext{
${ }^{18}$ Lévinas przedstawia podmiotowość przez pryzmat gościnność, w której Toż-Samy przyjmuje drugiego człowieka. Emmanuel LÉVINAs, Całość i nieskończoność. Esej o zewnętrzności, przeł. Małgorzata Kowalska, seria: Biblioteka Współczesnych Filozofów (Warszawa: Wydawnictwo Naukowe PWN, 1996), 11, 201, 360.
} 
między ja i innym powraca pytanie o tożsamość i uniwersalne wartości. Nie chodzi o to, aby, odpowiadając na pytanie o tożsamość $j a$, odrzucić inność drugiej osoby, lecz o to, by ją zachować. Tylko wówczas, gdy przedstawiam drugiego jako absolutnie innego, oddzieloną ode mnie osobę i jej relację ze mną, pokazuję moją tożsamość. To inny, wzywając mnie, przywraca mi refleksję nad sensem mojego istnienia. Mogę być dla innego, a zatem jestem. To odwrócenie kartezjańskiego cogito ergo sum ${ }^{19}$. U Kartezjusza akcent pada na $j a, \mathrm{w}$ filozofii dialogu — uwypuklony jest inny, lecz nie jako ktoś daleki, ale ten, o którym myślę, o którego troszczę się. Empatia, altruizm wskazują na moją tożsamość. Świadomość bliskiej obecności innych przywraca mi sens istnienia. Myśleć to jednak nie znaczy traktować innego jako przedmiot, lecz jako tego, na którym mi zależy. Myśleć to troszczyć się o innego. Przez wieki wartości pojawiały się między mną i ideą dobra, imperatywem, który nakazywał mi ich urzeczywistnienie. Współczesna filozofia, powracając do korzeni kultury europejskiej, zwraca się ku innemu, o którego jestem zatroskany, któremu ufam. Sama inność jest pojęciem dwuznacznym, można ją różnie rozumieć, ale ten, kto niesie z sobą inność, jest konkretny, ma twarz. Lévinas zwraca uwagę na twarz sieroty, wdowy i obcokrajowca $^{20}$. To ci, którzy nie tylko są obcy dla mnie, ale są również wyrwani ze świata, w którym kluczową rolę odgrywa wzajemność. Owa wzajemność, rozumiana jest raczej jako symetryczność w społeczeństwie: coś od siebie daję i w zamian czegoś oczekuję. Jest coś bardzo ważnego, co łączy problem uchodźców i filozofię innego, jest to źródłowe doświadczenie innego. Filozofia dialogu idzie jeszcze o krok dalej, ponieważ w każdym człowieku dostrzega potrzebę dialogu, w którym konstytuuje się prawda o nas samych. To spotkanie innego czy — w przypadku dialogu — drugiego człowieka musi mieć jakąś podstawę, otwartość ${ }^{21}$.

Czy jednak otwartość nie naraża podmiotu na zranienie? Czy istnieje jakaś granica otwartości? Jeśli istnieje, to ogranicza gościnność. Jeśli goszczę innego, zabieram go do siebie, podejmuję go w sferze prywatnej, jaką jest mój dom. Goszczenie kogoś wiąże się z przyjęciem zobowiązania bycia odpowiedzialnym za innego. Bezgraniczne ofiarowanie się komuś innemu, kto może być wdowa, sierota czy obcokrajowcem, nie przynależy do świata,

\footnotetext{
${ }^{19}$ LÉVINAS, Całość i nieskończoność, 88.

${ }^{20}$ Ibid., 256.

${ }^{21}$ Ks. Józef Tischner w Filozofii dramatu wspomina o trzech formach otwartości. Są nimi otwartość na świat, na przepływający czas i na drugiego. Józef Tischner, Filozofia dramatu (Paris: Éditions du dialogue. Société d'éditions internationales, 1990), s. 11.
} 
w którym czuję się bezpiecznie. Nic nie wiem o nich, jestem otwarty na kogoś, kto może mnie skrzywdzić. Dlatego ofiarowanie siebie wiąże się $\mathrm{z}$ ryzykiem, ale i doświadczeniem czegoś wyjątkowego, tj. bliskości innego.

\subsubsection{PROBLEM MIGRACJI PRZEZ PRYZMAT INNEGO}

Także inny w spotkaniu naraża się na zranienie. Lévinas dostrzega we wspomnianej wdowie, sierocie i obcokrajowcu kogoś, kto uprzedza mnie w prośbie o pomoc. Są oni utożsamiani z kimś, kto jest słaby, a nawet uznanymi za kogoś, komu czegoś brakuje. Levinas w swoje książce Całość $i$ nieskończoność stwierdza:

Brak wspólnej ojczyzny sprawia, że Inny jest Obcym: Obcym, który zakłóca moje „u siebie”. Ale Obcy znaczy wolny. W stosunku do niego nie mogę móc, nie mogę mieć żadnej władzy. Wymyka się ona mojemu panowaniu w istotny sposób, nawet jeżeli nim dysponuję. Nie mieści się w moim miejscu. Ale ja, który nie mam wspólnego pojęcia z Obcym, ja również, tak jak on, nie należę do żadnego rodzaju. Jesteśmy Toż-Samym i Innym. Spójnik „,i” nie oznacza tu żadnego łączenia ani władzy jednego terminu nad drugim ${ }^{22}$.

Spójnik ,i” (copula), o którym wspomina także Heidegger, analizując problem źródłowego doświadczenia prawdy ${ }^{23}$, wskazuje na swoisty sposób wchodzenia $\mathrm{w}$ relację $\mathrm{z}$ innym. Dokonuje się ono poprzez dyskurs, w którym nie chodzi o to, aby poznać drugiego, by go zdominować, lecz o to, aby znaleźć przestrzeń, w której mogę otworzyć się na innego, który woła mnie po imieniu. Lévinas za Husserlem dostrzega, że nie sposób dotrzeć do innego, ponieważ między nami istnieje przepaść. Z biegiem czasu Husserl doszedł do przekonania, że ten dystans może skrócić komunikacja ${ }^{24}$. Lévinas natomiast koncentruje się na dyskursie, który nie niszcząc dystansu, umożliwia relację.

Kultura europejska skoncentrowana na $j a$, podmiocie poznania, nie może uchwycić innego przez pryzmat innego. Zawsze czyni to przez pryzmat siebie. Głęboko jednak w kulturze osadzona jest miłość, która ukazuje silną wieź, umożliwiającą wejście w kontakt z drugą osobą.

\footnotetext{
${ }^{22}$ LÉVINAS, Całość i nieskończoność, 26.

${ }^{23}$ Martin Heidegger, Bycie i czas, przeł. Bogdan Baran, seria: Biblioteka Współczesnych Filozofów (Warszawa: Wydawnictwo Naukowe PWN, 1994), 226, 490, 504. Oryg.: Martin HeIdEgGER, Sein und Zeit, red. Friedrich-Wilhelm Herrmann i Vittorio Klostermann (Tübingen: Max Niemeyer Verlag, 1993), 159-160, 349, 360

${ }^{24}$ Krystyna Święcicka, Husserl (Warszawa: Wiedza Powszechna, 1993), 36.
} 
Oswald Spengler charakteryzuje kulturę Zachodu przez pryzmat prasymbolu, którym jest przestrzeń nieskończoności, i wieszczy jej upadek ${ }^{25}$. Także Nietzsche, żyjący jeszcze przed ukazaniem się w 1917 r. dzieła Spenglera Upadek Zachodu, dostrzega w kulturze europejskiej degenerację. Widzi ją w moralności mieszczaństwa, które kultywuje prawdę tylko wówczas, gdy mu ona służy. W XX wieku Żyd polskiego pochodzenia Jakob Leib Talmon w swoim dziele The Origins of Totalitarian Democracy ${ }^{26}$ analizuje źródło totalitaryzmu w kulturze europejskiej przez pryzmat dwóch szkół demokracji powstałych po wybuchu rewolucji francuskiej ${ }^{27}$. Wtedy etyka oparta na religii przekształciła się w etykę, dla której istotnym elementem staje się korzyść. Obie te szkoły mają za podstawę wolność. Talmon krytycznie ocenia oświecenie i dostrzega w Europie konsekwencje oświeceniowego sposobu myślenia.

Rewolucja, podobnie jak industrializacja, zmieniła kulturę Zachodu. Wiele zmian spowodowały również wojny światowe w Europie. Nastąpił upadek kultury, której kryterium stała się praktyczność, skuteczność. Tuż przed wojnami pojawia się jednak zjawisko odwrotne - pogłębiona refleksja nad drugim człowiekiem. Powstaje wówczas filozofia dialogu, a wcześniej, na gruncie biblistyki, nurt hermeneutyczny czy fenomenologia.

Jeden z przedstawicieli nurtu fenomenologicznego, Max Scheler, ukazuje problem wartości przez pryzmat współodpowiedzialności. Krytykując Kanta, który redukował zmysłowość do sfery utylitarnej, Scheler dostrzega współodpowiedzialność w sympatii (gr. $\sigma v \mu \pi \alpha ́ \theta \varepsilon \imath \alpha$ ), współczuciu, którego doświadczamy, zanim pojmujemy rozumem ${ }^{28}$. To pewnego rodzaju powrót do korzeni kultury europejskiej, czyli wolności, tolerancji i braterstwa. Scheler, odpowiadając na zarzuty kierowane przez Nietzschego wobec chrześcijaństwa, zauważa, że subiektywne wartości niosą w sobie uniwersalizm dobra. To pojęcie dobra, które pojawiło się wraz z chrześcijaństwem, zmieniło kulturę europejską na wieki, wcześniejsze skupianie się na pięknie zmieniło się w idee braterstwa, u którego podstaw jest doznanie dobra.

Współcześnie dobro przestało być ideą, a stało się doświadczeniem wspólnym, które najlepiej oddaje pojęcie solidarności i współodpowiedzialności ${ }^{29}$.

\footnotetext{
${ }^{25}$ Oswald Spengler, Zmierzch zachodu. Zarys morfologii historii uniwersalnej, przeł. Józef Marzęcki (Warszawa: Wydawnictwo KR, 2001), 47-60, 121.

${ }^{26}$ TALMON, „O demokracji totalitarnej”, 71.

${ }^{27}$ Ibid., $68-70$.

${ }^{28}$ Max SCHELER, Istota i forma sympatii, przeł. Adam Węgrzecki (Warszawa: PWN, 1986), 21 nn.; Max Scheler, Der Formalismus in der Ethik und die materiale Wertethik, Neuer versuch der Grundlegung eines ethischen Personalismus (Bern, München: Francke Verlag, 1966), 283-284.

${ }^{29}$ Scheler, Der Formalismus, 516; Karol WojtyŁa, Osoba i czyn oraz inne studia antropologiczne (Lublin: TNKUL, 1994), 323.
} 
Ta sama kultura, ale w nowym świetle. Uzmysłowiliśmy sobie, że urzeczywistnienie dobra konstytuuje się w przestrzeni pomiędzy mną a innym. $\mathrm{W}$ ten prasymbol przestrzeni nieskończonej wkroczyło doświadczanie spotkania. Jego zapowiedź znajduje się nie tylko w filozofii, ale i w literaturze, także tej, która ukazała się parę wieków wcześniej, jak np. Boska komedia Dantego, do której wraca Hans Urs von Balthasar ${ }^{30}$, ale i Józef Tischner, ukazując, że największym złem jest zerwanie dialogu ${ }^{31}$.

Kultura, której jeśli nie samo doświadczenie, to przynajmniej idea nawiązuje do otwartości, boryka się z nie lada wyzwaniem, jakim jest integracja w czasie wzmożonych wędrówek, w czasie kryzysu migracyjnego. Czy ta kultura wytrzyma napór kultur alternatywnych? Trudno na to pytanie odpowiedzieć, lecz od samego początku w kulturze europejskiej kluczową rolę odgrywał synkretyzm, włączanie do niej różnych kultur.

Problem integracji, od czasu powstania państw wielokulturowych w państwach narodowych, jak i współczesny kryzys migracji każą nam ponownie przyjrzeć się relacjom między kulturami.

\subsection{PROBLEM MIGRACJI WIDZIANEJ PRZEZ PRYZMAT ISTNIEJACYCH OBOK SIEBIE KULTUR}

Migracja ludności dokonywała się od samego początku istnienia ludzkości. Wynikała ona z przyczyn prozaicznych, takich jak zdobywanie pożywienia czy poszukiwanie bezpiecznego miejsca do osiedlenia się. Mówi się, że kolebką ludzkości jest Afryka, natomiast kultura kulinarna wywodzi się z Azji. Ludność wędrowała, a z czasem zaczęła budować osady, posługiwała się określonymi przedmiotami. Tworzyła cywilizacje, a w nich różne kultury. Cywilizacja to system komunikacji, system monetarny, posługiwanie się pewnym instrumentarium. Kultura opiera się na pewnych formach więzi, które ukazują się poprzez przyjęte wspólne symbole, wyobrażenia, pamięć. Kultura to nie tylko sztuka dostrzegana w literaturze, muzyce albo malarstwie, lecz również sztuka kulinarna. To na ich przykładzie ukazuje się charakterystyczna cecha określonej społeczności, wspólnoty. W obrębie jednej społeczności występują różne kultury, różne tradycje. To wówczas stawiamy sobie pytanie o sens i formy wzajemnych relacji między kulturami, szczególnie wśród ludności przybywającej do danego kraju. Jaki powinien być ich

\footnotetext{
${ }^{30}$ Hans Urs von Bathasar, Chwała. Estetyka teologiczna. 2 Modele teologiczne. Cz. 2: Od Dantego do Peguya, przeł. Jerzy Zakrzewski i Ewa Marszał (Kraków: Wydawnictwo WAM. 2009), 25.

${ }^{31}$ Józef Tischner, Spór o istnienie człowieka (Kraków: Znak, 1998), 11-13,
} 
wzajemny stosunek do siebie? Polityka wielokulturowa wpływa na integrację społeczno-ekonomiczną, integrację polityczną, jak również na integrację społeczno-kulturową. Ta ostatnia stanowi trzon, podstawę do integracji dostrzeganej w zewnętrznych efektach integracji społeczno-ekonomicznej ${ }^{32}$.

Zjawisko migracji występowało w różnych społecznościach, także w różnych jednostkach administracyjnych. Przejście od gościnności do integracji jest procesem, w którym podkreśla się kwestię wzajemności. Jest to możliwe tylko wtedy, gdy możliwe jest zbliżenie kulturowe, językowe i aksjologiczne. Jacques Derrida mówi o bezwarunkowej gościnności ${ }^{33}$, ale w przypadku kultury i języka chodzi również o symetrię w relacjach. W Sofiście Platona można nauczyć się czegoś od gościa. Migracja sprawia, że ludzie stają się coraz bardziej gospodarzem, ale także gościem, emigrantami i przybyszami. Istnieją migracje wewnątrz kraju, głównie z przyczyn ekonomicznych, ale także migracje zewnętrzne, gdy przybysz przebywa w innym kraju. Imigrant zmienia miejsce zamieszkania ze względów ekonomicznych i politycznych, często jest uchodźcą.

Problem uchodźców w Europie jest bardzo ważną kwestią. Podstawowym nieporozumieniem jest skojarzenie uchodźców z terrorystami. Tymczasem uchodźcy to w większości ludzie, którzy uciekają przed wojną. Negatywna ocena uchodźcy jest również wynikiem złej informacji na temat polityki emigracyjnej i ochrony przed terroryzmem. Przypadki ataków na ludność cywilną we Francji lub w Niemczech zmuszają nas do dbania o nasze bezpieczeństwo. Przyczyną terroryzmu nie jest jednak migracja ludzi, ale radykalizacja postaw i zachowań skrajnych frakcji islamskich. Migranci są też ofiarami terroru, podobnie jak Europejczycy, którzy boją się o własne życie w sytuacji, gdy nasilają się ataki terrorystyczne w Europie. Rozwiązanie konfliktu na Bliskim Wschodzie i zniesienie sieci przestępczych jest możliwe tylko przy zwiększonej integracji europejskiej. Tymczasem Europa boryka się z problemami nacjonalizmu i radykalnymi postawami państw narodowych, chcących podważyć wspólnotę europejską, która zapewniła pokój i bezpieczeństwo w Europie po $1945 \mathrm{r}^{34}$ Stopniowy rozwój integracji europejskiej zapewnił także względny dobrobyt obywatelom. Prawa człowieka są gwarancją stabilności i szczególną uwagę zwraca się w nich na mniejszości etniczne i religijne. Stabilność zapewnia nie tylko reprezentatywna większość, ale także poszanowanie praw mniejszości.

\footnotetext{
${ }^{32}$ FuKuYAma, Wielki Wstrząs, 19.

${ }^{33}$ Jacques DERRIDA, „Foreigner question”, w: Of hospitality: Anne Defourmantelle invites Jacques Derrida to respond, przel. Rachel Bowlby (Stanford: Stanford University Press, 2000), $135 \mathrm{nn}$.

${ }^{34}$ Schuman, Dla Europy, 20-21.
} 
Problem zarówno imigracji, jak i uchodźców staje się poważny i wymaga głębszej integracji. Strach wynika głównie z obawy przed utratą wspólnych wartości i z poczucia zagrożenia napływem ludzi z innych kultur, ale także z obawy przed utratą tożsamości narodowej lub kulturowej. Sposób okazywania strachu może mieć również pozytywne znaczenie, gorzej jednak jeśli ma charakter dialektyki, która opiera się na poszukiwaniu kozła ofiarnego ${ }^{35}$ i wykluczeniu grup mniejszościowych ${ }^{36}$.

Problem migracji można rozważać dwutorowo: po pierwsze, PRZEZ PRYZMAT PROCESU SOCJALIZACJI EMIGRANTÓw, po drugie z perspektywy KULTURY EUROPEJSKIEJ I MOŻLIWEGO ROZMYCIA JEJ FUNDAMENTÓW.

Proces socjalizacji to model, w jakim ten, który nazywa się uchodźcą, migrantem, staje się częścią naszej społeczności.

W historii pojawiały się różne modele, ukazujące proces transformacji kultur. Należy do nich AKULTURACJA ${ }^{37}$, a także INKULTURACJA ${ }^{38}$ czy ENKULTURACJA $^{39}$. Dotyczą one nie tyle wzajemnego przenikania się kultur, co raczej procesu dojrzewania w człowieku chęci do łączenia w sobie, kultywowania kultury autochtonicznej, którą nabywamy wzrastając w określonej tradycji, z kulturą. Kształtuje się w niej świadomość wspólnoty, w której bierze się udział w życiu społecznym. Szczególnie jest to widoczne w przypadku

\footnotetext{
${ }^{35}$ Kulturowym poszukiwaniem kozła ofiarnego zajmował się René Girard w swojej książce Le Bouc Emissaire (1982), czyli właśnie Kozioł ofiarny. Zauważa on, że każda kultura opiera się na dwóch elementach występujących w społeczeństwie, a mianowicie poszukiwaniu kozła ofiarnego i mimesis. Zob. René GiRARD, Kozioł ofiarny, przeł. Mirosława Goszczyńska, seria: Człowiek i jego cywilizacja (Łódź; Wydawnictwo Łódzkie, 1987), 62-70.

${ }^{36}$ Rainer Forst w swojej książce Toleranz im Konflikt koncentruje się na różnych typach tolerancji, takich jak Erlaubnis-Konzeption, poprzez Koexistenz-Konzeption, Respekt-Konzeption, Wertschaetzungs-Konzeption. Pierwsze dwie opierają się na stosunku większości grupy do mniejszości. W pierwszej chodzi o zasadę tolerancji, w której mniejszość nie ma takich samych praw jak większość, ponieważ jedynie większość może stanowić prawo, mniejszość natomiast tylko mu podlega. $\mathrm{W}$ drugim elementem kluczowym są relacje budowane ze względu na wspólną koegzystencję. Wszystkie z nich wskazują na pewne problemy z tolerancją, lecz dwa pierwsze zawierają w sobie walkę o wpływy. Rainer Fonst, Toleranz im Konflikt. Geschichte, Gehalt und Gegenwart eines umstrittenen Begriffs (Berlin: Suhrkamp, 2003), 42-48.

${ }^{37}$ Akulturacja może być interpretowana jako przyjmowanie przez jednostkę lub grupę kultury innej grupy. Ukazuje ona proces zmian kulturowych wynikających z istniejących różnic między kulturami znajdujących się w ciągłej i bezpośredniej konfrontacji, które prowadzą ostatecznie do stopniowych przekształceń w bezpośredniej interakcji.

${ }^{38}$ Inkulturacja jest stopniowym wzrastaniem jednostki lub grupy do innej kultury.

${ }^{39}$ Enkulturacja przedstawia zmiany kulturowe, których efektem jest fakt, że jednostka lub grupa staje się integralną częścią kultury i jej nośnikiem. Często proces ukazuje dojrzewanie młodego człowieka do identyfikacji z określoną kulturą. Dokonuje się on poprzez wychowanie, nauczanie, socjalizację jednostki.
} 
dzieci uchodźców, które stają na rozdrożu między tradycją wyniesioną od rodziców a wejściem w życie społeczne. W historii jednak mówiło się głównie o procesie przenikania się kultur w przypadku konfrontacji pewnych odrębnych kultur, np. w dobie kolonializmu pojawiła się kwestia INKULTURACJI. Stanowiła ona próbę zakorzenienia Ewangelii w kulturach autochtonicznych. Obok niej pojawia się również ENKULTURACJA, która oznacza nabycie nowych kompetencji kulturowych przez dzieci i młodzież, wchodzące w życie społeczne. Inny rodzajem relacji jest AKULTURACJA, która oznacza proces wyparcia jednej kultury w celu kultywowania innej. Mówi się również o procesie SOCJALIZACJI $^{40}$, która stanowi pewien złoty środek, poszukiwanie wspólnego fundamentu dla wspólnej egzystencji.

W wyniku procesu socjalizacji osoba przybywająca na obcy teren zdobywa pewne kompetencje kulturowe, społeczne, których wynikiem jest możliwość funkcjonowania w nowym społeczeństwie, lecz także oznacza poszanowanie wobec kultury przodków.

Po drugie, zagadnienia wzajemnych relacji międzykulturowych dotykają stawianego dziś pytania o kryzys kultury europejskiej. Czy grozi nam jej koniec? Czy kultura europejska oparta na tolerancji, poszanowaniu człowieka może być zdominowana czy wręcz wyparta przez nową kulturę?

Oswald Spengler analizuje różne kultury, zwracając uwagę na to, że każda $\mathrm{z}$ nich jest odrębnym bytem. Każda kultura ma jakiś prasymbol, na którego gruncie rozwija się i w końcu ginie. Dostrzega on, że kultura zachodnia opiera się na prasymbolu Fausta, w którym kluczową rolę odgrywa nieograniczona przestrzeń ${ }^{41}$. W oparciu o nią zbudowana jest współczesna kultura, która zmierza do pewnego końca. Wizja Spenglera ukazuje kulturę jako proces nieciągły. Po pewnej kulturze następuje inna, która zmienia prasymbol będący dla niej inspiracją. Jaki jest więc wzajemny stosunek między różnymi kulturami?

Wiek później po Spenglerze koniec kultury europejskiej wieszczą także Francis Fukuyama czy Michel Houellebecq. Bohater książki Houellebecqa Serotonina $^{42}$, Florent-Claude Labrouste, odczuwa lęk przed życiem, zażywa codziennie lek na depresję. rzyjmowanie leków na podniesienie poziomu

\footnotetext{
${ }^{40}$ Socjalizacja jest procesem, w którym jednostka lub grupa przejmuje od społeczeństwa wiedzę, kompetencje komunikacyjne, umiejętności i system wartości. Ten proces następuje bardzo powoli i trwa całe życie człowieka. Wyróżnia się on tym, że uwzględnia naturalne predyspozycje jak i uwarunkowania jednostki, która poznaje i uświadomią sobie bycie w określonej społeczności.

${ }^{41}$ SPENGLer, Zmierzch zachodu, 125.

${ }^{42}$ Michel HouellebecQ, Serotonina, przeł. Beata Geppert (Warszawa: Wydawnictwo W.A.B., 2019).
} 
serotoniny, „hormonu szczęścia”, mu nie wystarcza, jego problemem jest chęć wycofania się ze świata, w którym żyje. W tym celu wraca do przeszłości, do chwil, które minęły. Dotychczas akceptował życie, które wyglądało na ułożone, by potem dojść do przekonania, że jest ono nie do zniesienia, jest nudne i pozbawione sensu. Wiele w nim akceptacji dla fikcji i pozoru w imię zasad tolerancji i poprawności. Bohater zamierza, jak wiele osób, zniknąć, stać się niewidzialnym, odejść z życia, które rozczarowuje. To odejście oznacza powrót do przeszłości i do miłości, które minęły. Oprócz próby kontaktu z kobietami, o których przypomina sobie dokonując rozrachunku z przeszłością, trafia też na przyjaciela z czasów studenckich. Mieszkał na farmie z rodziną, która go później opuściła, podobnie jak przyjaciele. Został sam, świat mu się zawalił. Któregoś dnia poszedł na demonstrację rolników. To jedna ze scen, za którą Houellebecq uważany jest za proroka naszych czasów. Wszelako losy bohatera prowadzą w pewnym sensie do niespodziewanych wniosków. Bohater pozostaje w stanie silnej depresji, powrót do przeszłości uzmysławia mu jednak prawdziwy powód braku sensu istnienia - samotność. Wśród wielu ludzi jest sam, nikt nie potrafi go pokochać miłością bezwarunkową. On również nie jest bez winy: gdy miłość tę miał, nie potrafił jej pielęgnować. Serotonina jako hormon szczęścia wpływa na odczuwanie szczęścia przez wzmocnienie poczucia własnego $j a$, ale także na szczęście w relacji z innym człowiekiem. Właśnie tej relacji brakuje bohaterowi cierpiącemu na depresję.

W innej swojej książce, zatytułowanej Uległośc $c^{43}$, Houellebecq porusza problem powolnej transformacji ustrojowej $\mathrm{z}$ republiki w państwo wyznaniowe. W demokratycznych wyborach wygrywa Mohammed Ben Abbes, który jest przedstawicielem Bractwa Muzułmańskiego.

W tym wieszczeniu upadku przebłyskuje promyk nadziei. Kultura, o której wspomina Houellebecq, to kultura, za którą Europejczycy tęsknią. W zawirowaniu problemów cywilizacyjnych, przy wzroście konsumpcji i technizacji życia, pojawia się tęsknota, która ukazuje sens i podstawy kultury europejskiej. Podstawą jest kult indywiduum, które jest wolne i może podejmować różne wyzwania, za które ponosi odpowiedzialność. To jednak nie stanowi jeszcze jej źródła, jest nim bowiem właśnie relacja do drugiego człowieka. Może tym prasymbolem jest stosunek do siebie i do innego, szczególnie ważny w okresie rodzenia się chrześcijaństwa.

\footnotetext{
${ }^{43}$ Michel HouellebecQ, Uległość, przeł. Beata Geppert (Warszawa: Wydawnictwo W.A.B., 2020), $146 \mathrm{n}$.
} 
Jak w tej sytuacji możemy spojrzeć na integrację europejską i oferowane przez nią możliwości? Odpowiedź na to pytanie zależy od intensywności integracji i jej zrozumienia $\mathrm{w}$ kraju europejskim i u jego obywateli. Jak pokazują filozofie dialogu, ale także ks. Józef Tischner, zasadniczym problemem współczesnego człowieka i jego relacji jest wzajemność i otwartość na siebie nawzajem. W drugim przypadku, o którym mówiliśmy, oznacza to problem emigracji, gdy gość zamierza osiedlić się w kraju, do którego przyjechał. To nie tylko spotkanie człowieka z innym człowiekiem, ale także penetracja kultury. Wzajemność nabiera nowego kształtu. Dotyczy to problemu ludzkiego, ale także kultury, z której człowiek wyrasta, oraz tradycji i wartości, które pielęgnuje. W przypadku, gdy gość chce mieszkać w kraju, w którym został przyjęty gościnnie, gościnność powinna przerodzić się w proces dostosowywania się do praw gospodarza, do współistnienia, szacunku dla człowieka i kultury. Ta adaptacja jest nie tyle związana z prawem, ale bardziej z normami moralnymi i kulturowymi. Ten proces opiera się na poszanowaniu tradycji, nieodłącznie związanych z akceptacją i poszanowaniem europejskich norm i wartości.

Refleksja nad integracją europejską jest w pewnym sensie re-colere, stanowi powrót do pierwotnego źródła kultury jako colere $^{44}$ - uprawianie tego, co niematerialne. Stanowi refleksję, „rekolekcje” kultury, która jest żywa i potrzebuje rozwijającego ją dyskursu ${ }^{45}$. Być może właśnie to zmaganie się z różnorodnością kulturową stanowi głębszą refleksję nad istotą kultury europejskiej, której fundamentem jest wchłanianie tego, co obce.

\section{KONKLUZJA}

Integracja europejska jest procesem powolnym, ale trwałym. Nawet gdy mamy do czynienia $\mathrm{z}$ jej przeciwieństwem, czyli z dezintegracją, kultura europejska rozwija się. Oswald Spengler nie bierze pod uwagę faktu, że rozwój kultury odbywa się stopniowo i cyklicznie. Niekoniecznie mamy teraz do czynienia z końcem kultury, co raczej z fluktuacją, różnym natężeniem, jak i zmianą świadomości. Integracja to nic innego jak powrót do wspólnych wartości, które dostrzegamy w nowym świetle. Kryzys imigracyjny wydaje się zatrzymywać ten proces, ale w rzeczywistości pokazuje,

${ }^{44}$ Stownik tacińsko-polski, red. Józef Korpanty, t. 1 (Warszawa: Wydawnictwo Naukowe PWN, 2001), 349.

${ }^{45}$ Stownik łacińsko-polski, t. 2, 615. 
że Europejczycy potrzebują integracji Europy, szczególnie wobec procesu globalizacji. Dzisiaj bardziej dostrzegamy wspólne wartości niż wcześniej. Współczesna europejska filozofia pokazuje, że każdy z nas jest migrantem, szczególnie przez pryzmat religijny i kulturowy. Filozofia dialogu, o której mówiliśmy, wnosi do naszego myślenia ważny temat, jakim jest relacja między ja i drugim, innym. Nie tylko mityczna Europa, która przybyła na Kretę, inicjuje powstanie nowej kultury, ale także odwieczna tradycja pokazuje, że społeczność europejska czerpie inspirację do integracji ze spotkania z innymi kulturami. Wartości, których wcześniej nie zauważyliśmy, są oparte na relacji między człowiekiem a człowiekiem, na kulturze tolerancji i krytycznej refleksji nad sobą. Kultura europejska to kultura, którą poznaje się w odniesieniu do otaczającego świata, do innego.

Obecnie na drodze do pełnej integracji europejskiej stoi fala nacjonalizmu, ale także lęk przed obcą kulturą. Sposobem na przezwyciężenie tych problemów może być otwartość, która stanowi od początku powstania kultury europejskiej jej podstawową cechę. Mimo konfrontacyjnych wizji między kulturami kultura europejska przetrwa, jeżeli przetrwają Europejczycy, którzy myślą o niej, troszczą się o nią.

\section{BIBLIOGRAFIA}

Audisio, Giuseppe, i Albert Chiara. Twórcy zjednoczonej Europy Robert Schuman, Konrad Adenauer, Alcide de Gasperi. Przeł. Paweł Borkowski. Warszawa: Instytut Wydawniczt PAX, 2007.

DerridA, Jacques. Step of hospitality/no hospitality. W: Of hospitality: Anne Defourmantelle invites Jacques Derrida to respond. Przeł. Rachel Bowlby. Stanford: Stanford University Press 2000. Dostęp 31.07.2020. http://users.clas.ufl.edu/burt/shipwreck/derridahospitality.pdf

Dilthey, Wilhelm. Einleitung in die Geisteswissenschaften. Versuch einer Grundlegung für das Studium der Gesellschaft und der Geschichte. T. 1. Lepizig: Verlag Duncker und Humboldt, 1883.

Forst, Rainer. Toleranz im Konflikt. Geschichte, Gehalt und Gegenwart eines umstrittenen Begriffs. Suhrkamp Taschenbuch Wissenschaft. Berlin: Suhrkamp, 2003.

Funuyama, Francis. Zaufanie: kapitat spoteczny a droga do dobrobytu. Przeł. Anna i Leszek Śliwa. Warszawa, Wrocław: Wydawnictwo Naukowe PWN, 1997.

FukuYama, Francis. Wielki Wstrzas. Natura ludzka a odbudowa porzadku społecznego. Przeł. Hanna Komorowska i Krzysztof Dorosz. Warszawa: Politeja, 2000.

Guarini, Guarino. Żywot Platona. Przeł. Tomasz Płóciennik. W: Humanistyczne żywoty filozofów starożytnych, red. Włodzimierz Olszaniec i Krzysztof Rzepkowski, 195-278. Seria: Biblioteka Renesansowa 1. Warszawa: Wydawnictwo Uniwersytetu Warszawskiego, 2008. 
Girard, René. Kozioł ofiarny. Przeł. Mirosława Goszczyńska. Seria: Człowiek i jego cywilizacja. Łódź: Wydawnictwo Łódzkie, 1987.

Heidegger, Martin. Sein und Zeit, red. Friedrich-Wilhelm Herrmann i Vittorio Klostermann. Tübingen: Max Niemeyer Verlag, 1993.

Heidegger, Martin. Bycie i czas. Przeł. Bogdan Baran. Seria: Biblioteka Współczesnych Filozofów. Warszawa: Wydawnictwo Naukowe PWN, 1994.

Houellebecq, Michel. Serotonina. Przeł. Beata Geppert. Warszawa: Wydawnictwo W.A.B., 2019.

HouellebecQ, Michel. Uległość. Przeł. Beata Geppert. Warszawa: Wydawnictwo W.A.B., 2020.

JAEGER, Werner. Teologia wczesnych filozofów greckich. Przeł. Jerzy Wocial. Kraków: Homini, 2007.

Knowles, M. David, i Dmitri Obolensky. Historia Kościoła. T. 2. Przeł. Ryszard Turzyński. Warszawa: Instytut Wydawniczy PAX, 1988.

Lauden, Rachel. Cusine and Empire. Cooking in World History: Berkeley, Los Angeles, London: University of California Press, 2014.

LÉVInAs, Emmanuel. Całość i nieskończoność. Esej o zewnętrzności. Przeł. Małgorzata Kowalska. Seria: Biblioteka Współczesnych Filozofów. Warszawa: Wydawnictwo Naukowe PWN, 1996.

MarciniaK, Katarzyna. Mitologia grecka i rzymska. Spotkania ponad czasem. Warszawa, Bielsko: Wydawnictwo Szkolne PWN, 2010.

Scheler, Max. Der Formalismus in der Ethik und die materiale Wertethik. Neuer versuch der Grundlegung eines ethischen Personalismus. Bern, München: Francke Verlag, 1966.

SCHELER, Max. Istota i forma sympatii. Przeł. Adam Węgrzecki. Warszawa: PWN, 1986.

Schuman, Robert. Dla Europy. Przeł. Magdalena Krzeptowska. Kraków: Wydawnictwo Znak, 2009.

Słownik grecko-polski, red. Zofia Abramowiczówna. T. III. Warszawa: PWN, 1962.

Stownik tacińsko-polski, red. Józef Korpanty. T. 1. Warszawa: Wydawnictwo Naukowe PWN, 2001; T. 2. Warszawa: Wydawnictwo Naukowe PWN, 2003.

SPengler, Oswald. Zmierzch zachodu. Zarys morfologii historii uniwersalnej. Przeł. Józef Marzęcki. Warszawa: Wydawnictwo KR, 2001.

ŚwięCICKA, Krystyna. Husserl, Warszawa: Wiedza Powszechna, 1993.

TALMON, Jacob Leib. „O demokracji totalitarnej”. Znak 1992, nr 2 (443): 67-80.

Tischner, Józef. Spór o istnienie człowieka. Kraków: Znak, 1998.

Tischner, Józef. Filozofia dramatu. Paris: Editions du dialogue. Société d'éditions internationales, 1990.

Urs von Balthasar, Hans. Chwała. Estetyka teologiczna. 2 Modele teologiczne. Cz. 2: Od Dantego do Peguya. Przeł. Jerzy Zakrzewski i Ewa Marszał. Kraków: Wydawnictwo WAM. 2009.

WojtYŁA, Karol. Osoba i czyn oraz inne studia antropologiczne. Lublin: TN KUL, 1994.

\section{INTEGRACJA I RELACJE MIĘDZYKULTUROWE WCZORAJ I DZISIAJ: FILOZOFIA MIGRACJI}

Streszczenie

W niniejszym artykule poruszony został problem integracji w kulturze europejskiej. Proces integracyjny stanowi ważny element każdej kultury. W kulturze europejskiej pojawił się on na samym początku, gdy kultura ta powstawała, i trwa przez cały czas jej rozwoju, choć przybiera 
różne formy w zależności od sytuacji społeczno-politycznej. Współczesna integracja nawiązuje do XVIII-wiecznego kształtowania się państw narodowych i konfrontacji z uniwersalnymi wartościami. Stosunek do innych kultur i tożsamość europejska odsyłają do takich wartości, jak wspólne dobro, wolność czy odpowiedzialność. Jak pokazuje filozofia XX-wieku, ważnym elementem stała się relacja między ja i innym, drugim. Wartości kształtują się między nami. Przez ten pryzmat możemy dostrzec problem migracji, której podstawą jest walka o prawa człowieka. Wokół tej walki powstaje tożsamość europejska. Relacje międzyludzkie ukazują znaczenie i sens migracji, która inspiruje Europę do pogłębionej integracji.

Słowa kluczowe: integracja; migracje; inny; relacje międzykulturowe; tożsamość; wartości; Europa; proces socjalizacji.

\section{INTEGRATION AND INTERCULTURAL RELATIONS IN THE PAST AND IN THE FUTURE: A PHILOSOPHY OF MIGRATION}

\section{S u m m a ry}

In this article is presented the problem of integration in European culture. The integration process is an important element of European culture. It appears at the beginning when this culture arose as a result of taking over some elements of other cultures in its development. Contemporary integration refers to the eighteenth-century formation of nation-states and confrontation with universal values. Attitude towards other cultures and European identity refers to such values as common good, freedom or responsibility. As the philosophy of the twentieth century shows, an important element has become the relationship between me and another, the interlocutor. The experiences of values constitute between us. Through this lens, we can observe the problem of migration, which is based on the fight for human rights. It is around her that European identity is created. These interpersonal relationships reveal the meaning and sense of migration, which for Europe are inspirations for deeper integration.

Key words: integration; migration; other; intercultural relation; identity; values; Europe; process of socialization. 